\title{
A Study on the Effect of Time Duration by Vibrating or Tamping Fresh Concrete on the Compressive Strength of C-25 Concrete
}

\author{
Afework Achalu ${ }^{1}$, Emer Tucay Quezon ${ }^{2}$, Gerry Bangayan Macarubbo ${ }^{3}$ \\ ${ }^{1}$ Construction Engineering and Management, School of Civil and Environmental Engineering, Jimma Institute of Technology, Jimma \\ University, Jimma, Ethiopia \\ ${ }^{2}$ Construction and Engineering Management Stream, School of Civil and Environmental Engineering, Jimma Institute of Technology, Jimma \\ University, Jimma, Ethiopia \\ ${ }^{3}$ School of Civil and Environmental Engineering, Jimma Institute of Technology, Jimma University, Jimma, Ethiopia
}

\section{Email address:}

afeworkachalu@yahoo.com (A. Achalu), quezonet09@gmail.com (E. T. Quezon), quezonet09@yahoo.com (E. T. Quezon), gerrymacarubbo@yahoo.com (G. B. Macarubbo)

\section{To cite this article:}

Afework Achalu, Emer Tucay Quezon, Gerry Bangayan Macarubbo. A Study on the Effect of Time Duration by Vibrating or Tamping Fresh Concrete on the Compressive Strength of C-25 Concrete. American Journal of Applied Scientific Research. Vol. 3, No. 6, 2017 , pp. 72-79. doi: 10.11648/j.ajasr.20170306.11

Received: January 29, 2017; Accepted: February 23, 2017; Published: November 28, 2017

\begin{abstract}
Many years ago, consolidation accomplished by laborers wielding a variety of spades, tampers, and similar tools. In Ethiopia, there is no enough knowledge by the laborers, while the site engineers ignored the correct application due to some constraints. The agreement of acceptable vibration level in fresh concrete to which tamping time duration is optimum is an issue to obtain the desired specific compressive strength. This research study aims to evaluate the maximum time length and techniques used to the Vibrating or Tamping fresh concrete and its effect on the compressive strength of C-25 Concrete through internal Rodding. Therefore, to study the effects of the period by vibrating or tamping, the needle type internal vibrator was used to test new concrete cubes based on ACI309R-96. The quality of concrete is important to make physical tests on materials used before any actual experiments to perform. The fresh concrete samples tested by using internal vibration methods and techniques of compaction with different time duration of $1 \mathrm{sec}, 2 \mathrm{sec}, 3 \mathrm{sec}, 4 \mathrm{sec}$, and $5 \mathrm{sec}$. These tests performed by using steel rod in fresh concrete to know the Optimum time of compaction by internal vibration on the cube test of new concrete. Laboratory experiments had been conducted to check the methods and techniques applied to construction sites, as well as site observation on the effects of the vibration time of fresh concrete on the compressive strength and flexural strength of C-25 Concrete with varying vibration time duration and steel rod tamping. Based on the results of cube tests of compressive strength of Concrete Samples have been checked at $3^{\text {rd }}$ day, $7^{\text {th }}$ day and the $28^{\text {th }}$ day. This research study found out that the Optimum period of compaction was $3 \mathrm{sec}$ to produce an acceptable right quality of the concrete mix. Likewise, the flexural strength of Concrete Sample, when it tested in the laboratory at $7^{\text {th }}$ day and $28^{\text {th }}$ day, the results revealed that the flexural strength improved when vibration time increased, but the amount of water has to be reduced to obtain the desired strength. Finally, Tamping is needed to place fresh concrete in the mold correctly. Furthermore, new concrete produced should match the properties and avoid improper tamping or vibration applications. This situation must not cause differences in compressive strength of concrete.
\end{abstract}

Keywords: Compressive Strength, Flexural Strength, Fresh Concrete, Internal Vibration, Normal Strength Concrete, Optimum Vibration Time, Rodding/Tamping

\section{Introduction}

Concrete material is the most common building material used in today's construction industry. It is a long- life and relatively low maintenance requirements add to its popularity. Concrete is a mixture of cement, water, and aggregate. 
Compacting can make concrete denser and stiffer and thus have an excellent compressive strength and low permeability [1]. Without proper compacting, high-quality concrete cannot achieve. Many years ago, consolidation accomplished by laborers wielding a variety of spades, tampers, and similar tools. Now, nearly all concrete consolidated with high-frequency vibrators. The purpose of compacting is to remove the air entrapped during concrete placement and to strengthen the Concrete into all the spaces in the formworks, including the corners and the gaps in the reinforcing steels [2]. If the concrete is not properly compacted, the air will remain inside the pores. When it hardens, the concrete, then appears with honeycomb spots or rashes.

As these spots contain a considerable amount of air, they compromise the strength and impermeability of the concrete. The poured concrete, therefore, needs to be consolidated to secure the necessary density, imperviousness, and strength as well as to improve its adhesion to the reinforcement bars. This consolidation can be done by hand with hand tampers or iron rods [3].

Today, there is little knowledge and agreement of acceptable vibration levels in early age concrete, and construction specifications are consequently very conservative to determine that vibration can increase concrete compressive strength, but some specific mixtures are more susceptible to segregation. Increases in the water-cement ratio, cement paste content, and quantity of coarse aggregate about fine aggregate were found to elevate the risk of isolation [4].

ACI Committee 309 R-96 recognized that vibration could improve concrete properties by removal of excess water and voids, but concrete of low viscosity is highly susceptible to segregation [5]. However, in Ethiopia researches and investigation are not yet done at an optimum vibration time of fresh concrete. Therefore, this research has investigated some benefits which obtained by the use of internal vibration methods and techniques on construction sites. To show the effects of different time duration on concrete properties of compressive strength and optimum vibration time of fresh concrete.

The primary focus of this research is to study the effects of time duration by vibrating or tamping of new concrete on the compressive strength. In the process of compaction, surface imperfections cause by either under Science in or over-vibration. Under vibration results in honeycombing, excessive entrapped air, and sand streaks. The results of over-vibration can be segregated, the form of deflection, the type of damage, and dirt streaks.

Internally vibrated, vertically cast concrete requires craftsmanship and must be done with care. Many European countries require a vibrator operator to be licensed, which can mean a 10-year apprenticeship. In the United States, no license required, and there are few consolidation courses available [6].

According to Concrete Works Materials Manual, undeveloped countries, consolidation or compaction accomplished by unskilled laborers wielding a variety of spades tampers and similar tools. The consequences of improper vibration on concrete make defects and may be the effects of the time duration of vibration on the concrete production.

This research aims to investigate the impact of vibration time and techniques used in vibrating or tamping of fresh concrete and its effect on compressive strength of C-25 Concrete through internal vibration.

\section{Materials and Methodology}

\subsection{Materials}

The materials used in this study are cement, fine aggregates, coarse aggregates, and water. The type of cement was Portland Pozzolana Cement (PPC) satisfying the Ethiopian Standard 1177-1CEM11\B-P 32.5R Grade, manufactured by Dangote Cement Factory. A sample of fine aggregates was taken from Gambela Region due to unavailability in the study area. While the coarse aggregates were extracted from the quarry site in the Jimma area to fulfill the testing requirements. The coarse aggregates are locally known as "Gebreal Sefer" with Grade 01 and 02 . The water utilized in the concrete mix was drinkable water supplied by the Jimma City Water and Sewerage Authority found in the laboratory area and the construction site.

\subsection{Concrete Mix Design and Materials Proportion}

The DOE Method of concrete mix design used to develop C-25 Concrete grade to obtain the target mean strength of $38 \mathrm{Mpa}$. This target mean strength is determined by considering $5 \%$ defects with a value of $\mathrm{K}=1$. 64. DOE recommended $8 \mathrm{Mpa}$ standard deviation in the absence of sufficient data [7]. The marginal value of $13 \mathrm{Mpa}$ was added in this study to specify strength, including the water-cement ratio of 0.59 . Also, the slump, considered $10 \mathrm{~mm}$ to $30 \mathrm{~mm}$ for the C-25 Concrete grade.

The volume of concrete materials calculated by using the physical properties of the materials. Table 1 shows some materials for one cubic meter for the $\mathrm{C}-25$ Concrete grade. The Standard cast iron molds of size $15 \mathrm{~cm} \times 15 \mathrm{~cm} \times 15 \mathrm{~cm}$ used in the preparation of Concrete cubes for compressive strength tests. While a standard cast iron mold of size $50 \mathrm{~cm} \mathrm{x}$ $10 \mathrm{~cm} \times 10 \mathrm{~cm}$ used for the flexural strength,

Table 1. Quantity of materials in $\mathrm{kg}$ for $1 \mathrm{~m}^{3} \mathrm{C}-25$ Concrete grade production.

\begin{tabular}{lllll}
\hline For C-25 Concrete grade; $\mathbf{W} / \mathbf{C}=\mathbf{0 . 5 9}$ & & & \\
\hline Materials & Cement $(\mathbf{K g})$ & Water $(\mathbf{L t})$ & Fine Aggregates $(\mathbf{K g})$ & Coarse Aggregates $(\mathrm{Kg})$ \\
\hline Quantities per $\left(\mathrm{m}^{3}\right)$ & 320 & 190 & 700 & 1210 \\
\hline
\end{tabular}




\subsection{Equipment Used for Vibration for the Experiment}

The internal vibrator used for cube test of concrete was (RB20-A, Changzhou Shi Hefeng Roben Machinery Co., Ltd., Jiangsu, China). It is a gasoline engine equipped with the flexible shaft internal vibrator, heads and shafts ZXRB (gasoline engine, Robin copy RB 20/5.0HP).

Engine type: Petrol ROBIN RB20

Speed no-load: 3600 revolutions per $\min (60 \mathrm{~Hz} /$ hertz/).

Vibrator Head: $32 \mathrm{~mm}, 38 \mathrm{~mm}, 45 \mathrm{~mm}, 50 \mathrm{~mm}, 60 \mathrm{~mm}$, $35 \mathrm{~mm}, 70 \mathrm{~mm}$. In this experiment, $32 \mathrm{~mm}$ vibrator head used.

Flexible pipe: $6 \mathrm{~m}$. Pipe, tube length of the experiment used. Operating weight: about $24 \mathrm{~kg}$

\subsection{Study Design}

Compliance of the materials with the standard specifications was verified before the casting of Concrete cubes. The Concrete mix composed of cement, fine aggregates, coarse aggregates, and water, were performed with an average vibration time of $1 \mathrm{sec}, 2 \mathrm{sec}, 3 \mathrm{sec}, 4 \mathrm{sec}$ and $5 \mathrm{sec}$ using the steel rod and tamp. The samples were tested for compressive strength at the ages of the $3^{\text {rd }}$ day, $7^{\text {th }}$ day and $28^{\text {th }}$ day. While the flexural strength only tested on the 7 th day and $28^{\text {th }}$ day.

\subsection{Sample Size and Sampling Procedures}

The purposive sampling selection process was employed in this research study. For the aggregates, the laboratory tests based on the laboratory manual by quartering and weighting of samples.

The Standard cast iron molds of size $150 \mathrm{~mm} \times 150 \mathrm{~mm}$ $\mathrm{x} 150 \mathrm{~mm}$ used in the preparation of Concrete cubes for compressive strength tests. The same material was prepared for the flexural strength using the standard cast iron molds of size $500 \mathrm{~mm} \times 100 \mathrm{~mm} \times 100 \mathrm{~mm}$. There were 54 samples, and 24 samples developed and cast for compressive strength tests and flexural strength tests, respectively.

\subsection{Study Variables}

a. The dependent variable of the Study is the compressive strength which depends on the factors that affect its strengths.

b. The independent variables of the study are: mix ratio; size and angularity of coarse aggregates; time and depth of rodding; and type of rod or tamper

\section{Results and Discussion}

\subsection{Effects of Vibration Time on the Properties of Fresh Concrete}

The laboratory experiments performed to test the effects of vibration or tamping period of Fresh Concrete on the compressive strength and flexural strength of $\mathrm{C}-25$ Concrete grade with varying vibration time and manually by Rodding.

The mix proportion, size, and shape of aggregates were checked to get a workable concrete mixture for a given period of compaction.

a. Mix proportions: The DOE Method of concrete was applied to cast conventional mixture of a C-25 Concrete grade. Throughout the experiment, 0.59 water-cement ratio was used, which provides with a slump of $0.25 \mathrm{~mm}$.

b. The size of aggregates: The Experimental investigation was a mixture of $20 \mathrm{~mm}$ and $10 \mathrm{~mm}$ diameter aggregate sizes. It was sieved and stored in different grades for blending. The maximum cast size of $19 \mathrm{~mm}$ diameter aggregate was used in the concrete mix design.

c. The shape of aggregates: The form of the aggregate influences the workability in good measure. Angular, elongated or flaky aggregate makes the concrete very harsh when compared to rounded aggregates or cubical shaped aggregates. From this concept, the coarse aggregate used for this research study was the crushed basaltic rock taken from the crusher site that was suitable for concrete making on its shape in the study area.

Based on the experiment, vibration at varying times and by Rodding showed significant effects on fresh concrete which was also depend on the workability and consistency of the concrete.

Usually, sufficient vibration applied as soon as the surface of the concrete has become relatively flat and air bubbles stop to break through the top surface. The Concrete samples vibrated at $3 \mathrm{sec}$ showed good characteristics, but the samples vibrated at $1 \mathrm{sec}$ and $5 \mathrm{sec}$, the characteristics are inferior performance. When little vibration applied on the fresh concrete, air bubbles did not dissipate out from the mixture, but when the concrete vibrated longer time, the new mix tends to be susceptible to segregation of aggregates.

\subsection{Effects of Vibration Time on the Compressive Strength of C-25 Concrete}

The quality and durability of standard concrete directly depend on the number and the shape of voids. So, to produce a durable concrete, it is necessary to reduce the amount of air trapped inside the concrete, which conducted by vibrating the concrete in the mixing stage or the casting stage.

The effects of vibration time assessed and the rate of compressive strength development has also investigated. For both investigation, experiments were carried out for fresh and hardened concrete with various Vibration time. For hardened concrete property, compressive strength tests performed with $15 \mathrm{~cm}$ cubes at the age of $3^{\text {rd }}$ day, $7^{\text {th }}$ day and $28^{\text {th }}$ day.

The research study shows that the compressive strength of standard concrete and high strength concrete decreases when water-cement ratio increases. Also, vibration or tamping period is another situation affecting the strength of concrete. When water-cement ratio increases, while at the same time Vibration time extends, the strength of concrete decreases. Similarly, when water-cement ratio decreases, and short Vibration time cause to reduce in Concrete strength as well. 


\subsubsection{Effects of Vibration Time Duration on the Compressive Strength of C-25 Concrete at the Age of 3 Days}

Table 2. Change in compressive strength with varying vibration time on the $3^{\text {rd }}$ day.

\begin{tabular}{|c|c|c|c|c|c|}
\hline \multirow{2}{*}{ W/C Ratio } & \multicolumn{5}{|c|}{ Vibration time (Sec) } \\
\hline & 1 & 2 & 3 & 4 & 5 \\
\hline \multirow{2}{*}{0.59} & \multicolumn{5}{|c|}{ Mean Compressive Strength } \\
\hline & 15.17 & 15.73 & 16.51 & 16.09 & 15.86 \\
\hline
\end{tabular}

At the age of 3 days, the observed rate of compressive strength development of $\mathrm{C}-25$ concrete that casts by $1 \mathrm{sec}$ was $15.17 \mathrm{MPa}$. While the Concrete cast by internal vibration method of $2 \mathrm{sec}$, the observed rate of compressive strength development was $15.73 \mathrm{MPa}$. This result indicated that the rate of compressive strength development increased by $0.56 \mathrm{Mpa}(3.56 \%)$ from the Concrete cast by $1 \mathrm{sec}$ vibration time.

At $3 \mathrm{sec}$ vibration of concrete, the observed rate of compressive strength development was $16.51 \mathrm{MPa}$, which was increased by $1.34 \mathrm{MPa}(4.95 \%)$ from the $1 \mathrm{sec}$, while at $4 \mathrm{sec}$ there was a decreased in a strength of $0.42 \mathrm{Mpa}(-2.54 \%)$. Extending $1 \mathrm{sec}$ to make it a total $5 \mathrm{Sec}, 0.23 \mathrm{Mpa}(-1.43 \%)$ reduction in strength. The results showed that for $1 \mathrm{sec}$ and $5 \mathrm{sec}$ vibration time duration, it was under and over vibration because of its low and high vibration applied. The compressive strength of low vibration became weak when compared to other solid cast with the same specimen. Segregation of aggregates occurred beyond $3 \mathrm{sec}$ Vibration time.

\subsubsection{Effects of Vibration Time Duration on the Compressive Strength of C-25 Concrete at the Age of 7 Days}

Table 3. Change in compressive strength with varying vibration time on the $7^{\text {th }}$ day.

\begin{tabular}{|c|c|c|c|c|c|}
\hline \multirow{2}{*}{ W/C Ratio } & \multicolumn{5}{|c|}{ Vibration time (Sec) } \\
\hline & 1 & 2 & 3 & 4 & 5 \\
\hline \multirow{2}{*}{0.59} & \multicolumn{5}{|c|}{ Mean Compressive Strength } \\
\hline & 22.06 & 23.03 & 25.37 & 23.44 & 23.22 \\
\hline
\end{tabular}

At the age of 7 days, the observed rates of compressive strength development of $1 \mathrm{sec}, 2 \mathrm{sec}$, $3 \mathrm{sec}, 4 \mathrm{sec}$, and $5 \mathrm{sec}$ vibration time cast Concrete were $22.06 \mathrm{MPa}, 23.03 \mathrm{MPa}$, 25.33MPa, 23.44MPa, and 23.22MPa, respectively. These results indicate the observed rate of compressive strength development increased from $0.97 \mathrm{Mpa}(4.38 \%)$ to $2.34 \mathrm{Mpa}$ $(10.16 \%)$ considering from $1 \mathrm{sec}, 2 \mathrm{sec}$, and $3 \mathrm{sec}$. But after $3 \mathrm{sec}$ of vibration, there were significantly decreased of compressive strength of $1.93 \mathrm{Mpa}(-7.61 \%)$ when extended to $4 \mathrm{sec}$, and $0.22 \mathrm{Mpa}(-0.94 \%)$ decreased for $5 \mathrm{sec}$. The reason for increasing Vibration time is to remove the entrapped air bubbles from Concrete samples and to determine the optimum vibration time, which gives out the strongest bond in concrete between aggregate and mortar.

\subsubsection{Effects of Vibration Time Duration on the Compressive Strength of C-25 Concrete at the Age of 28 Days}

Table 4. Change in compressive strength with varying vibration time on the $28^{\text {th }}$ day.

\begin{tabular}{|c|c|c|c|c|c|}
\hline \multirow{2}{*}{ W/C Ratio } & \multicolumn{5}{|c|}{ Necessary time (Sec) } \\
\hline & 1 & 2 & 3 & 4 & 5 \\
\hline \multirow{2}{*}{0.59} & \multicolumn{5}{|c|}{ Mean Compressive Strength } \\
\hline & 33.16 & 35.12 & 37.12 & 35.95 & 35.21 \\
\hline
\end{tabular}

The laboratory test was extended up to 28 days. The result showed that the rates of compressive strength development of $1 \mathrm{sec}, 2 \mathrm{sec}, 3 \mathrm{sec}, 4 \mathrm{sec}$ and $5 \mathrm{sec}$ vibration time duration of concrete were $33.16 \mathrm{MPa}, 35.12 \mathrm{MPa}, 37.12 \mathrm{MPa}, 35.95 \mathrm{MPa}$, and $35.21 \mathrm{MPa}$, respectively. These values indicated the rate of compressive strength development of $2 \mathrm{sec}$ increased by $1.96 \mathrm{MPa}(5.92 \%)$ from $1 \mathrm{sec}$ vibrated concrete. Likewise, for the $3 \mathrm{sec}$ vibrated concrete increased by $3.96 \mathrm{MPa}(10.66 \%)$ based from $1 \mathrm{sec}$. Similar observations made on the $3^{\text {rd }}$ day and the $7^{\text {th }}$ day, by extending the time duration beyond $3 \mathrm{sec}$. In this test at $4 \mathrm{sec}$, there was decreased of $1.17 \mathrm{Mpa}(-3.52 \%)$, while at $5 \mathrm{sec}, 0.70 \mathrm{Mpa}(-1.95 \%)$ decreased in compressive strength.

The results revealed that there was a significant increase in compressive strength by increasing the vibration time up to $3 \mathrm{Sec}$ when tested at the age of 28 days. The big difference attributed to Concrete bond strength at the age of 28 days was due to complete the hydration reaction which makes the results more deviated according to each vibration time.

\subsubsection{Summary of the Effects of Vibration Time on the Compressive Strength of C-25 Concrete at the Age of $3^{\text {rd }}$, $7^{\text {th }}$ and $28^{\text {th }}$ Days}

Table 5. Change in compressive strength with varying Vibration time duration at the age of $3^{\text {rd }}, 7^{\text {th }}$ and $28^{\text {th }}$ days.

\begin{tabular}{llllll}
\hline \multirow{2}{*}{ Age (days) } & \multicolumn{6}{l}{ Vibration time (Sec) } \\
\cline { 2 - 6 } & $\mathbf{1}$ & $\mathbf{2}$ & $\mathbf{3}$ & $\mathbf{4}$ & $\mathbf{5}$ \\
\hline $3^{\text {rd }}$ & 15.17 & 15.73 & 16.51 & 16.09 & 15.86 \\
$7^{\text {th }}$ & 22.06 & 23.03 & 25.37 & 23.44 & 23.22 \\
$28^{\text {th }}$ & 33.16 & 35.12 & 37.12 & 35.95 & 35.21 \\
\hline
\end{tabular}

At the different ages of concrete, the observed rate of compressive strength development of C-25 Concrete that cast at $1 \mathrm{sec}, 2 \mathrm{sec}, 3 \mathrm{sec}, 4 \mathrm{sec}$, and $5 \mathrm{sec}$ increased by the amount of vibration applied as shown in Table 5.

For all the tests as shown, $1 \mathrm{sec}$ and $5 \mathrm{sec}$ vibration time duration Concrete represented under and over vibration because of low and high vibration applied to the fresh concrete. The compressive strength became weak when compared to other Concrete casts with the same specimens. The segregation of aggregates occurred beyond $3 \mathrm{sec}$ Vibration time as evidence of decreasing compressive strengths when extended up to $5 \mathrm{sec}$. 


\subsection{Effects of Rodding on the Compressive Strength of C-25 Concrete at the Age of $3^{\text {rd }}$, $7^{\text {th }}$ and $28^{\text {th }}$ Days}

Table 6. Change in compressive strength with Rodding.

\begin{tabular}{llll}
\hline \multirow{2}{*}{ Age (days) } & \multicolumn{3}{l}{ Compaction by Rodding } \\
\cline { 2 - 4 } & $\mathbf{3}^{\text {rd }}$ & $\mathbf{7}^{\text {th }}$ & $\mathbf{2 8}^{\text {th }}$ \\
\hline Mean Compressive Strength & 15.31 & 23.34 & 34.06 \\
\hline
\end{tabular}

For compaction of concrete by Rodding at the age of 3 days, the observed rate of low compressive strength development of C-25 concrete that cast by Rodding was 15.31MPa. Also, when compacted by Rodding, a higher amount of removed air bubbles from fresh concrete showed a better bond between mortars and aggregate.

At the age of 7 days, the development of concrete showed there was an improvement in compressive strength of 23.34MPa. The reason for increasing compressive strength by Rodding is due to the removal of entrapped air bubbles from Concrete samples which give out a stronger bond in concrete between aggregate and mortar.

At the age of 28 days, the observed rate of compressive strength development was $34.06 \mathrm{MPa}$; a $45.92 \%$ compressive strength increased from the $7^{\text {th }}$-day test results of a concrete specimen. The big difference between the ages of testing the concrete specimen attributed to Concrete bond strength at this period.

\subsection{Experimental Results and Discussion on the Strength of Concrete with Varying Vibration Time Duration and Rodding}

Table 7. Change in compressive strength of C-25 concrete with varying Vibration time and Rodding.

\begin{tabular}{|c|c|c|c|c|c|c|c|c|}
\hline \multicolumn{9}{|c|}{ Mean value of compressive strength test of $C-25$ concrete } \\
\hline \multirow{2}{*}{$\begin{array}{l}\text { Vibration } \\
\text { Time (Sec) }\end{array}$} & \multirow{2}{*}{$\begin{array}{l}\text { W/C } \\
\text { Ratio }\end{array}$} & \multirow{2}{*}{$\begin{array}{l}\text { Slump } \\
(\mathbf{m m})\end{array}$} & \multicolumn{2}{|l|}{$3^{\text {rd }}$ day } & \multicolumn{2}{|l|}{$7^{\text {th }}$ day } & \multicolumn{2}{|l|}{$28^{\text {th }}$ day } \\
\hline & & & $\begin{array}{l}\text { Failure Load } \\
(\mathrm{KN})\end{array}$ & $\begin{array}{l}\text { Comp. } \\
\text { Strength (Mpa) }\end{array}$ & $\begin{array}{l}\text { Failure Load } \\
(\mathrm{KN})\end{array}$ & $\begin{array}{l}\text { Comp. Strength } \\
\text { (Mpa) }\end{array}$ & $\begin{array}{l}\text { Failure Load } \\
(\mathbf{k N})\end{array}$ & $\begin{array}{l}\text { Comp. Strength } \\
\text { (Mpa) }\end{array}$ \\
\hline $1 \mathrm{sec}$ & 0.59 & 25 & 341.33 & 15.17 & 496.35 & 22.06 & 746.1 & 32.17 \\
\hline $2 \mathrm{sec}$ & 0.59 & 25 & 353.90 & 15.73 & 518.27 & 23.03 & 790.17 & 35.12 \\
\hline $3 \mathrm{sec}$ & 0.59 & 25 & 371.53 & 16.51 & 570.90 & 25.37 & 835.17 & 37.12 \\
\hline $4 \mathrm{sec}$ & 0.59 & 25 & 362.20 & 16.09 & 527.30 & 23.44 & 808.97 & 35.95 \\
\hline $5 \mathrm{sec}$ & 0.59 & 25 & 356.90 & 15.86 & 522.40 & 23.22 & 792.20 & 35.21 \\
\hline Rodding & 0.59 & 25 & 344.48 & 15.31 & 502.65 & 23.34 & 766.35 & 34.06 \\
\hline
\end{tabular}

In $1 \mathrm{sec}$ vibrated concrete at the age of 3 days, the observed rate of compressive strength development of $\mathrm{C}-25$ concrete was $15.17 \mathrm{MPa}$. While at the age of 7 days the observed rate of compressive strength development was $22.06 \mathrm{MPa}$. These values indicate that $6.89 \mathrm{MPa}$ increased the rate of compressive strength development and at the age of 28 days, the observed rate of compressive strength development was 33.16MPa.

These results showed the rate of compressive strength development increased by $17.99 \mathrm{MPa}$ and $11.1 \mathrm{MPa}$ from the $3^{\text {rd }}$ day and $7^{\text {th }}$-day concrete cast by $1 \mathrm{sec}$ vibration time, but it reduced from target mean strength because the Vibration time duration was very low for cube tests for the removal of entrapped air bubbles from Concrete samples. According to the observed test results conducted, it indicated the vibration applied on concrete was not enough to dense the Concrete bond and to get the Mean targeted strength of concrete.

In $2 \mathrm{sec}$ vibrated concrete at the age of 3 days, the observed rate of compressive strength development of $\mathrm{C}-25$ concrete was $15.73 \mathrm{MPa}$. Similarly, at the age of 7 days, the observed rate of compressive strength development was $23.03 \mathrm{MPa}$. These results showed the rate of compressive strength development increased by 7.3 MPa and at the age of 28 days, the observed rate of compressive strength development was 35.12MPa.

This means that $19.39 \mathrm{MPa}$ and $12.09 \mathrm{MPa}$ increased the rate of compressive strength development for the $3^{\text {rd }}$ and cast Concrete cast by $2 \mathrm{sec}$ vibration time. According to the observed test results conducted, the compressive strength of
2 sec vibrated concrete reduced from target mean strength because the Vibration duration was short for cube tests for the removal of all entrapped air bubbles from fresh concrete and decreased compressive strength at 28 days might be related to fully hydrated reaction in long term ages.

In $3 \mathrm{sec}$ vibrated concrete at the age of 3 days, the observed rate of compressive strength development of C-25 concrete was $16.51 \mathrm{MPa}$. Similarly, at the age of 7 days, the observed rate of compressive strength development was $25.37 \mathrm{MPa}$. These values indicated that $8.86 \mathrm{MPa}$ increased the rate of compressive strength development, while at the age of 28 days the observed rate of compressive strength development was 37.12MPa.

These values show that the rate of compressive strength development increased by $20.61 \mathrm{MPa}$ and $11.75 \mathrm{MPa}$ from the $3^{\text {rd }}$ and $7^{\text {th }}$-day Concrete cast by $3 \mathrm{sec}$ vibration time. According to the observed test results conducted, the compressive strength of $3 \mathrm{sec}$ vibrated concrete becomes relatively equal to the target mean strength considering $5 \%$ defects that have designed.

In $4 \mathrm{sec}$ vibrated concrete at the age of 3 days, the observed rate of compressive strength development of $\mathrm{C}-25$ concrete was $16.09 \mathrm{MPa}$. For the age of seven days, the observed rate of compressive strength development was $23.44 \mathrm{MPa}$. These values show $7.35 \mathrm{MPa}$ increased the rate of compressive strength development. At the age of 28 days, the observed rate of compressive strength development was $35.95 \mathrm{MPa}$.

Also, it showed that $19.86 \mathrm{MPa}$ and $12.51 \mathrm{MPa}$ increased the rate of compressive strength development from the $3^{\text {rd }}$ day and 
$7^{\text {th }}$-day Concrete cast by $4 \mathrm{sec}$ vibration time. Based on the observed test results conducted, the compressive strength of $4 \mathrm{sec}$ vibrated concrete reduced from the target mean strength that was designed. The test results further indicated that the Vibration applied at $4 \mathrm{sec}$ cast concrete cube was slightly over vibration.

According to ACI309R - 96, Normal weight concretes that are well proportioned and have adequate consistency are not readily susceptible to over vibration. Over vibration can occur if, due to a careless operation or use of grossly oversized equipment.

In $5 \mathrm{sec}$ vibrated concrete at the age of 3 days, the observed rate of compressive strength development of C-25 concrete was $15.86 \mathrm{MPa}$. Similarly, at the age of 7 days, the observed rate of compressive strength development was $23.22 \mathrm{MPa}$. The results obtained, indicated the rate of compressive strength development increased by $7.36 \mathrm{MPa}$ and at the age of 28 days, the observed rate of compressive strength development was 35.21MPa. It means that the rate of compressive strength development increased by $19.35 \mathrm{MPa}$ and $11.99 \mathrm{MPa}$ from the $3^{\text {rd }}$ day and $7^{\text {th }}$-day Concrete cast by $5 \mathrm{sec}$ vibration time. From the test results conducted, the compressive strength of $5 \mathrm{sec}$ vibrated Concrete reduced from the target mean strength that designed. This indicated the use of extended vibration time on cube test due to the greater amount of removed air bubbles from fresh concrete samples.

According to ACI309R-96, it recognized that vibrations had no consistent influence on the compressive strength of concrete, but vibration can improve Concrete properties by removal of excess water and voids.

The compaction of concrete by Rodding at the age of 3 days, the observed rate of Mean compressive strength development of $\mathrm{C}-25$ concrete that cast by Rodding was 15.31MPa. At the age of 7 days, the development of concrete was an improvement in compressive strength of 23.34MPa. While at the age of 28 days the observed rates of compressive strength development were $34.06 \mathrm{MPa}$.

These values indicated the rate of compressive strength development increased by $18.75 \mathrm{MPa}$ and $10.72 \mathrm{MPa}$ from the $3^{\text {rd }}$ day and $7^{\text {th }}$-day Concrete cast by Rodding. According to the observed test results conducted, the compressive strength of concrete cast by Rodding reduced from the target mean strength that designed. These results show that the compressive strength of concrete cast by Rodding was small for cube tests to the removal of entrapped air bubbles from Concrete samples. It further indicated the compaction applied on Concrete was not enough to dense the Concrete bond and to get the Mean targeted strength of concrete. From this result, the Concrete cast by Rodding was under vibration. So the decreased compressive strength at 28 days might be related to a fully hydrated reaction in long term ages.

According to ASTM Standards (C31 and C192) for making control specimens for strength tests: Either Rodding or vibration is permitted for slumps in the 1 to $3 \mathrm{in}$. (25 to $75 \mathrm{~mm}$ ) range. From the observed test results, compressive strength increases by increasing the vibration time, but the consequences of improper vibration have defects, and it varies the development of compressive strength of concrete specimens cast by changing Vibration time duration. On the strength of Specimen cast at $1 \mathrm{sec}, 2 \mathrm{sec}$ and by Rodding, the test results showed Vibration period was little for cube tests to remove entrapped air bubbles from Concrete samples.

The test results conducted, it indicated the vibration applied on Concrete was not enough to dense the Concrete bond, and to get the Mean targeted strength of concrete. The consequences of under vibration showed some defects like entrapped air voids (bug holes) on Concrete cast at $1 \mathrm{sec}$.

For the Concrete specimen casts at $4 \mathrm{sec}$ and $5 \mathrm{sec}$, the test results demonstrated that the vibration time duration was higher on cube test due to a higher amount of removed air bubbles from fresh concrete samples. These indicated the vibration applied on concrete cube performed better bond between mortar and aggregate, but it was susceptible for segregation of aggregates, because of higher vibration applied to the concrete. In other words, it is hard to achieve the Mean targeted strength of concrete. The consequence of over vibration would minimize the density of Concrete cast at $5 \mathrm{sec}$.

The laboratory experiments revealed that $3 \mathrm{sec}$ vibration time is optimum for $\mathrm{C}-25$ concrete. This test results based on the water-cement ratio used throughout the mixing design with varying internal Vibration time durations.

\subsection{Experimental Results and Discussion on Flexural Strength of Concrete Cast by Changing Vibration Time Duration at the Age of $7^{\text {th }}$ and $28^{\text {th }}$ Days}

The laboratory test performed on the 7 th day and the 28th day for $1 \mathrm{sec}, 2 \mathrm{sec}, 3 \mathrm{ec}, 4 \mathrm{sec}$, and $5 \mathrm{sec}$ vibrated Concrete. This experiment did manually by Rodding method of compaction. The results obtained from the experiment are tabulated in Table 8 below.

Table 8. Mean flexural strength test results with varying vibration time duration.

\begin{tabular}{|c|c|c|c|c|c|c|c|}
\hline \multirow{2}{*}{$\begin{array}{l}\text { Vibration time } \\
\text { (second) }\end{array}$} & \multirow[b]{2}{*}{ W/C Ratio } & \multirow{2}{*}{$\begin{array}{l}\text { Water } \\
\text { Reduction (\%) }\end{array}$} & \multirow[b]{2}{*}{ Slump (mm) } & \multicolumn{2}{|l|}{$7^{\text {th }}$ day } & \multicolumn{2}{|l|}{$28^{\text {th }}$ day } \\
\hline & & & & $\begin{array}{l}\text { Failure Load } \\
(\mathrm{KN})\end{array}$ & $\begin{array}{l}\text { Flexural } \\
\text { Strength (Mpa) }\end{array}$ & $\begin{array}{l}\text { Failure Load } \\
(\mathrm{KN})\end{array}$ & $\begin{array}{l}\text { Flexural } \\
\text { Strength (Mpa) }\end{array}$ \\
\hline $1 \mathrm{sec}$ & 0.59 & $5 \%$ & 20 & 4.05 & 3.05 & 6.75 & 5.05 \\
\hline $2 \mathrm{sec}$ & 0.59 & $5 \%$ & 20 & 4.7 & 3.53 & 6.85 & 5.15 \\
\hline $3 \mathrm{sec}$ & 0.59 & $5 \%$ & 20 & 5.25 & 3.65 & 7.35 & 5.5 \\
\hline $4 \mathrm{sec}$ & 0.59 & $5 \%$ & 20 & 5.65 & 4.22 & 7.7 & 5.8 \\
\hline Rodding & 0.59 & $5 \%$ & 20 & 4.35 & 3.25 & 6.75 & 5.05 \\
\hline
\end{tabular}


The values of flexural strength test for $\mathrm{C}-25$ with a varying time duration by reducing $5 \%$ the amount of mixing water at a consistent workability.

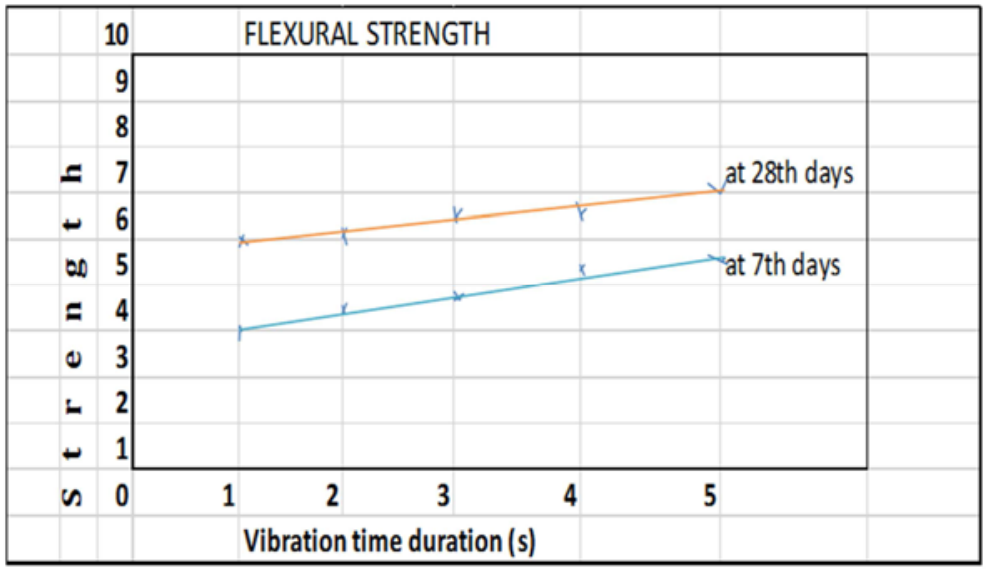

Figure 1. Offect of vibration time on flexural strength of concrete.

From Figure 1, it showed possible to save 5\% mixing water from standard concrete vibrated in varying time duration and to get high strength development at the age of $7^{\text {th }}$ day and $28^{\text {th }}$ day discussed as follows:

At the age of 7 days, the rate of flexural strength development of $1 \mathrm{sec}, 2 \mathrm{sec}, 3 \mathrm{sec}, 4 \mathrm{sec}$ and $5 \mathrm{sec}$ of vibrated concrete was $3.05 \mathrm{MPa}, 3.53 \mathrm{MPa}, 3.65 \mathrm{MPa}, 4.22 \mathrm{MPa}$, and $4.43 \mathrm{Mpa}$, respectively. These results indicated the rate of flexural strength development increased when the time of vibration increased. According to the test results, the rate of flexural strength development of $2 \mathrm{sec}$ vibrated concrete improved by $0.48 \mathrm{MPa}$ or $15.74 \%$ from $1 \mathrm{sec}$.

In $3 \mathrm{sec}$ vibrated concrete the rate of flexural strength development enhanced by $0.6 \mathrm{MPa}$ or $16.4 \%$ and $0.12 \mathrm{MPa}$ or $16.44 \%$, but it reduced by $0.57 \mathrm{Mpa}$ or $13.5 \%, 0.69 \mathrm{MPa}$ or $17.61 \%$ from $4 \mathrm{sec}$ and $5 \mathrm{sec}$ vibrated concrete. In $5 \mathrm{sec}$ vibrated concrete the rate of flexural strength development was improved by $1.38 \mathrm{Mpa}$ or $31.15 \%, 0.9 \mathrm{MPa}$ or $20.32 \%$, $0.78 \mathrm{MPa}$ or $17.6 \%$ and $0.21 \mathrm{MPa} 4.74 \%$ from $1 \mathrm{sec}, 2 \mathrm{sec}, 3 \mathrm{sec}$ and $4 \mathrm{sec}$ vibrated concrete.

On the other hand, the specimen tested at 28 days, the rate of flexural strength development of $1 \mathrm{sec}, 2 \mathrm{sec}, 3 \mathrm{sec}, 4 \mathrm{sec}$ and $5 \mathrm{sec}$ vibrated concrete was $5.05 \mathrm{MPa}, 5.15 \mathrm{MPa}, 5.5 \mathrm{MPa}$, 5.8MPa, and 6.04MPa, respectively. These values indicated the rate of flexural strength development increased when a time of vibration increased. The test results show that the rate of flexural strength development of $2 \mathrm{sec}$ vibrated concrete was improved by $0.1 \mathrm{MPa}$ or $1.94 \%$ from $1 \mathrm{sec}$ vibrated concrete.

In $3 \mathrm{sec}$ vibrated concrete the rate of flexural strength development, improved by $0.45 \mathrm{MPa}$ or $8.18 \%$ and $0.35 \mathrm{MPa}$ or $6.4 \%$, but it reduced by $0.3 \mathrm{Mpa}$ or $5.17 \%, 0.54 \mathrm{MPa}$ or $8.94 \%$ from $4 \mathrm{sec}$ and $5 \mathrm{sec}$ vibrated concrete. According to the observed test results, it indicated the rate of flexural strength development increased when the time of vibration increased by reducing the amount of water that's used for mixing to prevent segregation of aggregates from the tested sample specimen.
At the age of 7 days, the rate of Mean flexural strength development of Concrete cast by Rodding was 3.25MPa, and at the age of 28 days, the rate of flexural strength development of concrete was 5.05MPa. These results revealed the rate of flexural strength development of Rodding concrete increased when compaction applied on it. The reason for the significant increase in flexural strength of concrete could be related directly to a removal of entrapped air bubbles form inside the concrete by increasing the vibration time.

The flexural strength had well improved when the Vibration time increased with the reduction of the amount of mixing water. Likewise, the flexural strength of concrete cast by Rodding increased at its $28^{\text {th }}$ day, but it reduced than cast by different vibration time duration except for $1 \mathrm{sec}$ vibration.

\subsection{Experimental Results and Discussion on Flexural Strength of Concrete}

The Concrete sample was supported at $4 \mathrm{~cm}$ towards its both ends and loaded at the interior (center) location by a gradual failure load. The failure load of which the concrete cracks were recorded in $\mathrm{Kn}$, while calculations were carried out to determine the flexural strength of Mpa. The rate of loading should be between the range from $0.04 \mathrm{MPa} / \mathrm{s}\left(\mathrm{N} / \mathrm{mm}^{2}\right.$. s) to $0.06 \mathrm{MPa} / \mathrm{s}\left(\mathrm{N} / \mathrm{mm}^{2} . \mathrm{s}\right)$.

At the age of 7 days, the rate of flexural strength development of $1 \mathrm{sec}, 2 \mathrm{sec}, 3 \mathrm{sec}, 4 \mathrm{sec}$ and $5 \mathrm{sec}$ of vibrated concrete was $3.05 \mathrm{MPa}, 3.53 \mathrm{MPa}, 3.65 \mathrm{MPa}, 4.22 \mathrm{MPa}$, and $4.43 \mathrm{MPa}$. While at the age of 28 days, the rate of flexural strength development of $1 \mathrm{sec}, 2 \mathrm{sec}, 3 \mathrm{sec}, 4 \mathrm{sec}$ and $5 \mathrm{sec}$ vibrated concrete was $5.05 \mathrm{MPa}, 5.15 \mathrm{MPa}, 5.5 \mathrm{MPa}, 5.8 \mathrm{MPa}$, and 6.04MPa, respectively.

These results indicated that the rate of flexural strength development increased when the time of vibration increased due to a removal of entrapped air bubbles form fresh concrete. The flexural strength was well improved when the Vibration time increased with the reduction of the amount of mixing water.

Also based on the test results, it showed that there was 
development increased from $1 \mathrm{sec}$ to $5 \mathrm{sec}$ of its flexural strength due to Rodding. But when it comes to vibration, the strength of the specimen reduced except Concrete cast at $1 \mathrm{sec}$.

\section{Conclusion}

In this research, the effects of vibration time duration on Concrete strength (i.e., Compressive and flexural) were experimentally investigated of C-25 concrete. When extended Vibration time above the maximum period on fresh concrete, it revealed the negative effect on the strength of concrete. Therefore, the reason for this change was the incremental time duration of Vibration above the Optimum time of $3 \mathrm{sec}$ causing concrete like fluid. The extended Vibration time above the optimum caused segregation of coarse aggregates affecting the compressive strength of concrete

On the other hand, when the vibration of fresh concrete is below the Optimum time duration, also it negatively affects the strength of concrete. The vibration time applied in the mixture is not enough to dense the Concrete bond and to get the Mean targeted strength. However, according to ACI 309R-96 recognized that vibrations had no consistent influence on the compressive strength of concrete, but vibration or tamping can improve Concrete properties by removal of excess water and voids. Therefore, this research study found out that the Optimum vibration time for C-25 concrete internally vibrated, and satisfied the requirement at $3 \mathrm{sec}$ vibration or tamping. The longer time or shorter time of the Optimum decreases the compressive strength of the Concrete.

\section{Recommendations}

The following recommendations are forwarded:

a. Start vibration when the stinger is submerged into the new concrete vertically and quickly (i.e., About 1 -foot per second), then withdraw slowly (i.e., About $3 \mathrm{sec}$ per foot); and,

b. Put the stinger into each portion of new concrete. When fresh concrete poured in layers, place the stinger about 6 inches in the previous layer, then stop vibration when the surface becomes shiny, and there are no more breaking air bubbles.

c. Proper attention should be undertaken in selecting the aggregate size and shape used for Concrete cast by vibration. The size and angularity of the coarse aggregates would affect the effort required to tamp the new concrete. The larger the size of aggregates, the greater the effort required, while the angular aggregates require greater effort than smooth or rounded aggregates.

\section{References}

[1] Concrete Works Materials Manual.

[2] Zongjin Li (2011), Advanced Concrete Technology.

[3] Concrete Works Manual 403 by ACI Committee U.S.A.

[4] ANOSIKE. M. N. (2011), Parameters for Good Site Concrete Production Management Practice in Nigeria July 2011.

[5] ACI 309 R-96, "Guide for Consolidation of Concrete," Reported.

[6] DUNAREA. D. J. (2004), the Annals of Concrete Consolidation and Vibration, University of Galati Fascicle XIV Mechanical Engineering.

[7] Design of Normal Concrete Mixes, $2^{\text {nd }}$ Edition by Building Research Establishment Ltd, the Transport Research Laboratory and the British Cement Association.

[8] Effects of Vibration time on the strength of Ordinary and High-Performance Concrete, Department of Civil Engineering, Karadeniz Technical University, Trabzon/Turkey http://www.ktu.edu.tr.

[9] Ethiopian Building Code Standard for Structural Use of Concrete /EBCS-2/, Addis Ababa, 1995.

[10] Impact of Vibrations on the Final Characteristics of Normal and Self-compacting concrete.

[11] N. Suresh Professor, NIE, Mysore- Workability of concrete.

[12] Omoregie, A. (2012). Impact of Vibration, Time on Compressive Strength of Hardened Concrete, Building Blocks School of Built Environment and Engineering, University of Bolton (UK), UAE Campus, Al Hudaiba-Bareraat.

[13] Sedigheh S, (2012). Effect of Vibration, Time on Some Mechanical Properties of High Strength Steel Fiber Reinforced Concrete, Institute of Graduate Studies and Research in Partial Fulfillment of the Requirements for the Degree of Master of Science in Civil Engineering, Eastern Mediterranean University January 2012 Gazimağusa, North Cyprus. 